\title{
TRANSPORTATION PROCESS OPTIMIZATION - SELECTED EXAMPLE
}

\author{
AGNIESZKA WANIEWSKA, ${ }^{1}$ PAULINA KRAWCZYSZYN, ${ }^{2}$ \\ MAGDALENA KOWACKA ${ }^{3}$
}

Wyższa Szkoła Oficerska Wojsk Lądowych imienia generała Tadeusza Kościuszki we Wrocławiu, Wydział Zarządzania, POLAND

1 e-mail: a.waniewska@wso.wroc.pl

2 e-mail: p.krawczyszyn@wso.wroc.pl

${ }^{3}$ e-mail: m.kowacka@wso.wroc.pl

\begin{abstract}
RECEIVED
9 August 2017

ACCEPTED

15 December 2017

JEL

CLASSIFICATION

$\mathrm{M} 14, \mathrm{R} 40$

KEYWORDS

optimization, transport, logistic, AHP method

ABSTRACT

Due to the dynamic world growth, people more often need to choosetheoptimal mean of transport. To do it properly, experts correlate many transport offers and compare such features as: time of transit, costs, capacity. But it should be mentioned, that process of collecting, comparing and studying the data is a time consuming process. The article presents how the AHP method could be used as an aid to choose the optimal mean of transport. The method is widely used not only because of high effectiveness of resolving complex problems, but also because it is simple and the results are transparent and easy to interpret. Several significant parameters were chosen to conduct theanalysis.
\end{abstract}

\section{Introduction}

The AHP method was developed and described by Saaty. It is mainly used as an aid tool during complex decision making process. During that process, the user can select physical objects and states that representthe project or other variants, that could lead to the certain states (quality, risk). What is more, diagnostic and comparative evaluation of examined objects is possible by using the AHP method (Downarowicz, Krause, Sikorski, 
Stachowski, 2000, p. 7). The assumption is, that the AHP method would make it easier to choose optimum variant inthemulticriterial optimizing, especially because of its reduction to theseries of comparison in pairs (Emrouznejad, Marra, 2017, p. 6653). The method has many advantages, but the fact that both measurable and nonmeasurable features can be used inthe analysis should be considered as the most crucial issue (Mu, Pereyra-Rojas, 2017). The aim of the article is to show possible usage of the AHP method in transportation problem.

\section{Literature review}

Because of thecomparison in pairs of all elements with each other, standard evaluation scales are insufficient. To make the analysis more complete, the 9-point grade scale was introduced. Comparing two elements with each other will show which is more significant and how much (Przybyło, Krężołek, 2017).

When we want to comparethe elements that are nonmeasurable, the linguistic approach should be applied. In that approach, the linguistic variable takes as its value the verbal definition. In order to evaluatethe elements on different levels in the analyzed structure, the comparison matrix was created (Cabała, 2010, pp. 5-23), and its degree is equal to thenumber of compared elements (Mu, Pereyra-Rojas, 2017).

$$
A=\left[\begin{array}{cccc}
a_{11}=1 & a_{12} & \ldots & a_{1 n} \\
a_{21}=\frac{1}{a_{12}} & 1 & \ldots & a_{2 n} \\
\ldots & \ldots & \ldots & \ldots \\
a_{n 1}=\frac{1}{a_{1 n}} & 1 & \ldots & a_{m n}
\end{array}\right]
$$

where: $A$ - square matrix where aij denote the elements of the matrix $(i, j=1,2, \ldots, n)$; the matrix is called square if: ${ }^{1}$

a) $a_{i j}=z$, then $a_{j i}=\frac{1}{z}, z \neq 0$

b) criteria $C_{i}$ is equiponderant to $C_{j}$, then $a_{i j}=1 \mathrm{ia}_{j i}=1$, and $\mathrm{a}_{i j}=1$ for $i=j$.

Wherewith matrix A also fulfill the following property: $a_{i j}>0, a_{i j}=\frac{1}{a_{j i}} \forall i, j=1,2, \ldots, n$.

All the elements of the model are ordered according to validity ofthe priority vectors $W=w_{1}, \ldots, W_{n}$. Firstly, to calculate the priority vector $W$, it is necessary to perform a matrix $A$ normalization (the matrix $B$ is created), by dividing each element of the matrix by the sum of theelements in column, in which it is located (Mu, Pereyra-Rojas, 2017):

$$
b_{i j}=\frac{a_{i j}}{\sum_{i=1}^{n} a_{i j}}
$$

Next, average value in every row of the new matrix should be defined. That value is the element $w_{i}$ priority vector $W$ :

${ }^{1}$ http://www.dii.unisi.it/ mocenni/Note_AHP.pdf. 


$$
w_{i}=\frac{\sum_{j=1}^{n} b_{i j}}{n}
$$

where $i, j=1, \ldots, n$ wherein $\sum_{i=1}^{n} w_{i}=1$. In case of priority vectors analyzed criteria we use $k_{i}$, while forthe priority vector of theith element according to thejth criteria, we use $o_{i j}$.

Value of the AHP rate, denoted as $h_{i}$, is determined based on the dependence:

$$
h_{i}=\sum_{i=1}^{n}\left(k_{i} o_{i j}\right)
$$

where $k_{i}$ is the value of the priority vector element for theith criteria (wage of theith criterion), where as $o_{i j}$ is an value of the priority vector element for thejth object in terms of theith criterion, wherein $\sum_{i=1}^{n} h_{i}=1$.

Therefore, thecriteria and the variants comparison is made by defining superiority of one element over the other. The experts usually make that observation and because of that it is rather subjective opinion. Even an experienced expert could make a mistake while studying data, what is most often caused by the lack of consequences duringthe evaluation (Mu, Pereyra-Rojas, 2017).

According to E. Mu and M. Pereyra-Rojas, checking the credibility of results in the AHP method should be made by calculating the consistency ratio from theunder mentioned formula:

$$
C R=\frac{C I}{R I} 100 \%
$$

where:

RI - Random Consistency Index, gaining values from 0 to 1.57 (Table 1),

$\mathrm{Cl}$ - Consistency Index, we define from dependence:

$$
C I=\frac{\left(\lambda_{\max }-n\right)}{(n-1)}
$$

where $\lambda_{\max }$ is maximum value from the matrix, always higher or equal to rank of the matrix $n$.

Table 1. Random Consistency Index RI

\begin{tabular}{cccccccccccccccc}
\hline Matrix order number & $n$ & 1 & 2 & 3 & 4 & 5 & 6 & 7 & 8 & 9 & 10 & 11 & 12 & 13 & 14 \\
\hline $\mathrm{RI}$ & $\mathrm{RI}$ & 0.00 & 0.00 & 0.58 & 0.90 & 1.12 & 1.24 & 1.32 & 1.41 & 1.45 & 1.49 & 1.51 & 1.54 & 1.56 & 1.57 \\
\hline
\end{tabular}

Source: Mu, Pereyra-Rojas (2017).

Maximum estimated value of the matrix $\lambda_{\max }$ can be calculated asthe amount of sums of theproducts averaged in row normalized values of wages and sum of columns referring each criteria, what can be written as (Ginda, 2007): 


$$
\lambda_{\max }=\sum_{i=1}^{n}\left(w_{i} \sum_{j=1}^{n} a_{i j}\right)
$$

The value of the consistency ratio $C R$ should not exceed $10 \%$, because it will mean that the evaluation process must be repeated (Mu, Pereyra-Rojas, 2017).

\section{Method}

Using above information, the authors decided to use the AHP method to conduct thesimulation of thedecision making process, where theoptimal mean of transport has to be chosen. There are five criteria in analysis: speed, transport availability, capacity, transport costs, exploitation reliability. What is more, there are 6 different means of transport taken into account: heavy-loaded truck, truck, train, ship, ferry, airplane.

First part of the analysis is to make thecriteria ranking, what is shown in Table 2. Secondly, it is necessary to normalize the criteria ranking, what is presented in 3th Table.

Table 2. Criteria ranking

\begin{tabular}{lccccc}
\cline { 2 - 5 } & Speed & Transport availability & Capacity & Transport costs & Exploitation reliability \\
\hline Speed & 1.00 & 0.33 & 0.14 & 5.00 & 0.11 \\
Transport availability & 3.00 & 1.00 & 0.20 & 5.00 & 0.11 \\
Capacity & 7.00 & 5.00 & 1.00 & 7.00 & 0.11 \\
Transport costs & 0.20 & 0.20 & 0.14 & 1.00 & 0.11 \\
Exploitation reliability & 9.00 & 9.00 & 9.00 & 9.00 & 1.00 \\
\hline Sum & 20.20 & 15.53 & 10.49 & 27.00 & 1.44 \\
\hline
\end{tabular}

Source: own work.

Table 3. Normalized criteria ranking

\begin{tabular}{lccccc} 
& Speed & Transport availability & Capacity & Transport costs & Exploitation reliability \\
\hline Speed & 0.05 & 0.02 & 0.01 & 0.19 & 0.08 \\
Transport availability & 0.15 & 0.06 & 0.02 & 0.19 & 0.08 \\
Capacity & 0.35 & 0.32 & 0.10 & 0.26 & 0.08 \\
Transport costs & 0.01 & 0.01 & 0.01 & 0.04 & 0.08 \\
Exploitation reliability & 0.45 & 0.58 & 0.86 & 0.33 & 0.69 \\
\hline Sum & 1.00 & 1.00 & 1.00 & 1.00 & 1.00 \\
\hline
\end{tabular}

Source: own work.

Calculations in that method are rather complex but repetitive and because of that the authors decided to omit some of it in further part of the article. Next part of the analysis is the alternative ranking of all the alternatives in all the criteria. Table 4. shows example of the alternatives ranking according tothe exploitation reliability criteria.

In that case, $C R=0.04$. In other criteria, the $C R$ is:

- speed-0.09,

- transport availability $-0,05$, 
- capacity - 0.08,

- transport costs -0.06 .

That values show, that the $\mathrm{CR}$ is optimum in every case. After building the pairwise comparison matrices, the decision maker could point out thescore vectors, that are shown in Table 5.

Table 4. Ranking ofthe alternatives according to the exploitation reliability criteria

\begin{tabular}{lcccccc}
\hline \multicolumn{1}{c}{ Exploitation reliability } & Truck & $\begin{array}{c}\text { Heavy-loaded } \\
\text { truck }\end{array}$ & Train & Ship & Ferry & Airplane \\
\hline Truck & 1 & 0.33 & 0.11 & 0.20 & 0.20 & 0.14 \\
Heavy-loaded truck & 3 & 1.00 & 0.14 & 0.33 & 0.33 & 0.20 \\
Train & 9 & 7.00 & 1.00 & 5.00 & 5.00 & 3.00 \\
Ship & 5 & 3.00 & 0.20 & 1.00 & 1.00 & 0.33 \\
Ferry & 5 & 3.00 & 0.20 & 1.00 & 1.00 & 0.33 \\
Airplane & 7 & 5.00 & 0.33 & 3.00 & 3.00 & 1.00 \\
\hline Sum & 30 & 19.33 & 1.99 & 10.53 & 10.53 & 5.01 \\
\hline
\end{tabular}

Source: own work.

Table 5. Score vectors in each criteria

\begin{tabular}{lccccc}
\cline { 2 - 5 } & Speed & Transport availability & Capacity & Transport costs & Exploitation reliability \\
\hline Truck & 0.11 & 0.32 & 0.03 & 0.05 & 0.03 \\
Heavy-loaded truck & 0.11 & 0.32 & 0.05 & 0.05 & 0.05 \\
Train & 0.18 & 0.20 & 0.09 & 0.03 & 0.45 \\
Ship & 0.03 & 0.06 & 0.35 & 0.18 & 0.11 \\
Ferry & 0.03 & 0.06 & 0.35 & 0.18 & 0.11 \\
Airplane & 0.53 & 0.03 & 0.14 & 0.51 & 0.24 \\
\hline
\end{tabular}

Source: own work.

Next, the score vectors should be multiply by the priority vector and the sum in rows. The results are shown in Table 6.

Table 6. Overall priority for variants

\begin{tabular}{lc}
\cline { 2 - 2 } & \\
\hline Truck & Priority vectors \\
Heavy-loaded truck & 0.06 \\
Train & 0.08 \\
Ship & 0.31 \\
Ferry & 0.16 \\
Airplane & 0.16 \\
\hline
\end{tabular}

Source: own work.

According to the calculations and the initial assumptions, optimal mean of transport in that case is train. 


\section{Conclusions}

Taking everything into consideration, the AHP method is one of the mathematical method that support the decision-making process in complex and multicriterial problems (Lu, Qin, Jin, 2017). That method is an aid, especially for those who are not enough experienced in some fields. The AHP method grant an optimum solution to be chosen fromthe different alternatives. Among many advantages, the most valuable is that duringthe decisionmaking process the problem can be seen from different perspectives and complex problem could be reduced to thesimple mathematical equations. Thanks to that, taken decision is not biased or influenced by theone issue.

\section{References}

Cabała, P. (2010). Using the analytic hierarchy process in evaluating decision alternatives. Operations Research and Decisions, 1 , $5-23$.

Downarowicz, O., Krause, J., Sikorski, M., Stachowski, W. (2000). Zastosowanie metody AHP do oceny i sterowania poziomem bezpieczeństwa złożonego obiektu technicznego. Gdańsk.

Emrouznejad, A., Marra, M. (2017). The state of the art development of AHP (1979-2017): a literature review with a social network analysis. International Journal of Production Research, 55, 6653-6675.

Ginda, G. (2007). Forecasting based on multiatribute analysis. Forecasting and simulations. Politechnika Opolska. Retrieved from: http://www.bopis.po.opole.pl/pis06_win.pdf (2.08.2017).

http://www.dii.unisi.it/ mocenni/Note_AHP.pdf.

Lu, Z.Y., Qin, F.T., Jin, Y.C. (2017). Study on the Algorithm of Judgment Matrix in Analytic Hierarchy Process. International Conference on Cloud Technology and Communication Engineering. Journal of Physics Conference Series, 910.

Mu, E., Pereyra-Rojas, M. (2017). Practical Decision Making, Chapter 2: Understanding the analytic hierarchy process. SpringerBriefs in Operations Research.

Przybyło, W., Krężołek, S. (2017). Zastosowania AHP w budownictwie. Retrieved from: www.fema.pl/ mit/PUBLIKACJE_WLASNE/ doc/ahpwbsk-olsztyn.doc (30.07.2017).

Cite this article aS." Waniewska, A., Krawczyszyn, P., Kowacka, M. (2018). Transportation process optimization - selected example. European Journal of Service Management, 2 (26), 323-328. DOI: 10.18276/ejsm.2018.26-40. 